\title{
Lactobacillus plantarum YS-3 Prevents Activated Carbon-Induced Constipation in Mice
}

\author{
Xin Zhao, ${ }^{1,2}$ Ruokun Yi, Yu Qian, and Kun-Young Park ${ }^{2,3}$ \\ ${ }^{1}$ Beijing Advanced Innovation Center for Food Nutrition and Human Health, \\ Beijing Technology and Business University (BTBU), Beijing, China. \\ ${ }^{2}$ Chongqing Collaborative Innovation Center for Functional Food, Chongqing \\ University of Education, Chongqing, China. \\ ${ }^{3}$ Department of Food Science and Biotechnology, Cha University, \\ Seongnam, Gyeongghi-do, Korea.
}

\begin{abstract}
The aim of this study was to determine the effects of Lactobacillus plantarum YS-3 (LP-YS3) on activated carboninduced constipation in Kunming mice. The results of the experiment show that the antigastric acid activity and bile salt tolerance of LP-YS3 were stronger than those of Lactobacillus bulgaricus (LB). LP-YS3 inhibited loss of body weight caused by constipation and further reductions in fecal weight, particle number, and water content in mice. Moreover, LP-YS3 elevated the gastrointestinal transit rate and reduced the time required for initial black stool defecation. LP-YS3 also elevated motilin (MTL), endothelin (ET), acetylcholinesterase (AChE), substance P (SP), and VIP serum levels and reduced somatostatin (SS) levels in constipated mice. Hematoxylin-eosin (H\&E) staining revealed that high concentration of LP-YS3 reduced the incidence of injuries to small intestine villi and the intestinal wall compared to carbon-induced constipation groups. Reverse transcription-polymerase chain reaction and western blot experiments demonstrated that LP-YS3 upregulated c-Kit, stem cell factor, and glial cell line-derived neurotrophic factor mRNA and protein expression and downregulated transient receptor potential vanilloid 1 and nitric oxide synthase expression in small intestine tissue from constipated mice. In conclusion, high concentrations of LP-YS3 had stronger and more beneficial effects than LB. Based on these results, we conclude that LP-YS3 can effectively inhibit constipation.
\end{abstract}

KEYWORDS: • constipation • gene expression • Lactobacillus bulgaricus • Lactobacillus plantarum YS-3

\section{INTRODUCTION}

$\mathbf{Y}$ AK SOUR MILK, a naturally fermented dairy product native to the Tibetan area of the Qinghai Tibet Plateau, is very rich in many types of nutrients with functionalities related to antioxidation, cholesterol reduction, and immune system regulation. ${ }^{1}$ Yak yogurt is formed under special natural fermentation conditions that includes fermented raw milk, fermentation temperature, total time, fermentation vessel, and especially the fermentation microorganism, which produces a distinct flavor and quality of yak yogurt. ${ }^{2}$ In this study, we isolated and identified lactic acid bacteria from yak sour milk in the Yushu Tibetan Autonomous Prefecture of Qinghai. We named one of these strains Lactobacillus plantarum YS-3 (LP-YS3) and performed further research.

Constipation is defined as a state in which the weekly defecation frequency is less than three, and severe con-

Manuscript received 19 October 2017. Revision accepted 14 January 2018.

Address correspondence to: Kun-Young Park, PhD, Department of Food Science and Biotechnology, Cha University, Bundang-gu, Seongnam 13488, Republic of Korea, E-mail: kunypark@cha.ac.kr stipation is when the frequency further decreases to once per week. Constipation is a threat to human health and has remarkably complex symptoms affecting colon health. ${ }^{3}$ Constipation is usually not considered as a disease, as it can be prevented or cured by regulating diet and lifestyle habits. ${ }^{4}$ In this study, we analyzed food physiological effects on constipation by establishing an animal constipation model. For this, we applied gastric-activated carbon to mice to activate the surface of the mucous membrane of the gastrointestinal (GI) tract. Activated carbon reduces water content and gastric juices in the digestive tract, thereby slowing GI motility and causing constipation. ${ }^{5}$

Large doses of activated charcoal can be used to block defecation. Our team previously investigated the preventive effects of lactic acid bacteria on constipation and observed reductions of initial black defecation time. Moreover, the preventive effects of lactic acid bacteria against constipation were further confirmed based on various indices such as serum motilin (MTL), gastrin (Gas), endothelin (ET), somatostatin (SS), acetylcholinesterase (AChE), substance $\mathrm{P}$ (SP), and vasoactive intestinal peptide (VIP) levels, which are commonly used evaluation indices when assessing Lactobacillus effects on constipation. ${ }^{6}$ Further, molecular 
level experiments can detect related mRNA expression levels in small intestine tissue to confirm the physiological effects of lactic acid bacteria.

In this study, the effects of LP-YS3 on constipation were evaluated, and Lactobacillus bulgaricus (LB) was used for the control group. First, we performed in vitro experiments to compare the tolerances of LP-YS3 and LB in artificial gastric juice and bile salt, thereby providing a preliminary understanding of the physiological role of LP-YS3 in GI activity. We further studied the active effects of LP-YS3 on constipation through animal experiments. The results of this study provide a theoretical foundation for the further development of LP-YS3 as a cure for constipation.

\section{MATERIALS AND METHODS}

\section{Experimental microorganism strains}

The lactic acid bacterium used was LP-YS3, and this strain was preserved in the China Center for Type Culture Collection (CCTCC No: 2016749, Wuhan, China) with the preservation number M2016749. L. bulgaricus (LB, CCTCC AB 200048) was purchased from the CCTCC.

\section{Detection of lactic acid bacteria tolerant to $\mathrm{pH} 3$ artificial gastric juice}

$\mathrm{NaCl}$ and pepsin were dissolved in distilled water with $\mathrm{pH}$ adjusted to 3 using $1 \mathrm{~mol} / \mathrm{L}$ of $\mathrm{HCl}$ to obtain a mass ratio of $0.2 \% \mathrm{NaCl}$ and $0.35 \%$ pepsin, followed by vacuum filtration to remove bacteria. Activated LP-YS3 was cultured, and $5 \mathrm{~mL}$ was extracted by centrifugation at $1100 \mathrm{~g}$ (iCEN-24, Allsheng, Hangzhou, Zhejiang, China) for $10 \mathrm{~min}$ to collect bacteria. Saline was added to obtain a $5-\mathrm{mL}$ bacterial suspension, which was mixed with artificial gastric juice at a volume ratio of 1-9. After shaking and culture for $3 \mathrm{~h}$ at $37^{\circ} \mathrm{C}$, we carefully measured the number of viable LP-YS3 bacteria at 0 and $3 \mathrm{~h}$ to calculate the tolerance of lactic acid bacteria to artificial gastric juice $(\%)=$ viable count $(\mathrm{CFU} / \mathrm{mL})$ at $3 \mathrm{~h} /$ viable count $(\mathrm{CFU} / \mathrm{mL})$ at $0 \mathrm{~h} \times 100 \%{ }^{7}$

\section{Detection of bile salt tolerance of lactic acid bacteria}

LP-YS3 (2\% inoculum concentration) was inoculated into MRS-THIO culture medium containing $0.0 \%, 0.3 \%, 0.5 \%$, and $1 \%$ ox bile salt and then cultured for $24 \mathrm{~h}$ at $37^{\circ} \mathrm{C}$. Culture medium without LP-YS3 was used as the control group. We measured the absorbance value at $600 \mathrm{~nm}$ to obtain the bile salt tolerance of lactic acid bacteria $(\%)=$ Bile salt culture medium $\mathrm{OD}_{600} /$ blank medium $\mathrm{OD}_{600} \times 100$. $^{7}$

\section{Animal experiment}

Seven-week-old female Kunming mice were purchased from the experimental animal center of Chongqing Medical University (SYXK [Chongqing] 2012-0001). Mice were fed in a normal air, temperature, and humidity environment (temperature $\left[25^{\circ} \mathrm{C} \pm 2^{\circ} \mathrm{C}\right]$, relative humidity $[50 \% \pm 5 \%]$ ) under a $12 \mathrm{~h}$ light $/ 12 \mathrm{~h}$ dark cycle and with free access to standard mouse feed and water. A total of 100 Kunming mice weighing about $25 \mathrm{~g}$ each were divided into five groups: normal group, constipation control group, LB treatment group, low LP-YS3 concentration treatment group, and high LP-YS3 concentration treatment group. After 1 week of feeding, the normal and constipation control groups were allowed free access to normal diet and water for 2 weeks. The LB treatment group, low LP-YS3 concentration treatment (LP-YS3-L) group, and high LP-YS3 concentration (LPYS3-H) group were fed $2 \mathrm{~mL}$ of LB $\left(1.0 \times 10^{9} \mathrm{CFU} / \mathrm{kg}\right)$, $2 \mathrm{~mL}$ of LP-YS3 $\left(1.0 \times 10^{8} \mathrm{CFU} / \mathrm{kg}\right)$, and $2 \mathrm{~mL}$ of LP-YS3 $\left(1.0 \times 10^{9} \mathrm{CFU} / \mathrm{kg}\right)$, respectively, for 2 weeks in addition to normal diet and drinking water. After 2 weeks, mice from all groups except the normal group were intragastrically infused with $2 \mathrm{~mL}$ of $10 \%$ activated carbon water $(10 \%$ activated carbon mixed with $10 \%$ Arabia gum according to mass ratio to maintain the suspension) for 3 days. Meanwhile, lactic acid bacteria were fed to all mice. ${ }^{5}$ Weight, dietary intake, water consumption, fecal weight, and fecal humidity were measured at 9:00 a.m. daily during the experiment. The protocol of this experiment was approved by the Animal Ethics Committee of Chongqing Medical University.

\section{Determination of small intestinal propulsive rate and excretion time of activated carbon}

On day 17 of the experiment, after intragastric administration of activated carbon water, food was withheld from all mice, including the normal group, for $24 \mathrm{~h}$, although drinking water was still available. After $24 \mathrm{~h}, 0.2 \mathrm{~mL}$ of glacial activated carbon water was administered to all mice. Then, after $30 \mathrm{~min}$, half of the mice (10) from each group were killed by cervical dislocation and blood collected. The small intestine was removed to determine the recommended rate of activated carbon in the small intestine of mice. The recommended rate $(\%)=$ activated carbon propulsive distance/total length of small intestine $\times 100$. The remaining 10 mice in each group were used to determine the time of initial black stool.

\section{Determination of serum MTL, Gas, ET, SS, AChE, SP, and VIP levels in mice}

The collected mouse blood samples were centrifuged at $1650 \mathrm{~g}$ (iCEN-24, Allsheng, Hangzhou, Zhejiang, China) for $15 \mathrm{~min}$ to obtain serum, which was used to determine the levels of motilin (MTL), gastrin, endothelin-1 (ET-1), substance P (SP), somatostatin (SS), VIP, and acetylcholine enzyme (AChE) according to the kit instructions (Nanjing Jiancheng Bioengineering Institute, Nanjing, Jiangsu, China).

\section{Determination of small intestine tissue $M P O, N O$, GSH, and MDA levels in mice}

Small intestine tissues $(100 \mathrm{mg})$ were homogenized using phosphate-buffered saline on ice. Small intestine levels of myeloperoxidase (MPO), nitric oxide (NO), glutathione (GSH), and malondialdehyde (MDA) were determined using commercial kits (Cayman Chemical Co., Ann Arbor, MI, USA) according to the manufacturer's protocols. 
Reverse transcription-polymerase chain reaction assay

Small intestine tissue from mice were crushed, and general RNAs of colon tissue were extracted by RNAzol (Thermo Fisher Scientific, Inc., Waltham, MA, USA). The total RNA concentration was diluted to $1 \mu \mathrm{g} / \mu \mathrm{L}$. Then, $2 \mu \mathrm{L}$ of diluted general RNA extraction solution was added to $1 \mu \mathrm{L}$ each of oligodT18, RNase, dNTP, and MLV enzymes (Thermo Fisher Scientific, Inc.) and $10 \mu \mathrm{L}$ of $5 \times$ buffer to obtain cDNA at $37^{\circ} \mathrm{C}$ for $120 \mathrm{~min}, 99^{\circ} \mathrm{C}$ for $4 \mathrm{~min}$, and $4^{\circ} \mathrm{C}$ for $3 \mathrm{~min}$. Reverse transcription-polymerase chain reaction (RT-PCR) was performed to amplify c-Kit, stem cell factor (SCF), transient receptor potential cation channel subfamily $\mathrm{V}$ member 1 (TRPV1), glial cell-derived neurotrophic factor (GDNF), and NO synthase (NOS) (Thermo Fisher Scientific, Inc.) mRNA expression (Table 1), and the housekeeping gene GAPDH (glyceraldehyde-3-phosphate dehydrogenase) was used as the reference. Finally, electrophoresis on $1 \%$ agar gel was performed to measure amplified PCR products. ${ }^{8}$ ImageJ 1.44 software was used to conduct semi-quantitative analysis of the results.

\section{Western blot assay}

Small intestine tissue $(0.5 \mathrm{~g})$ was placed into $1 \mathrm{~mL}$ of cell lysate, ground with a homogenizer, and then centrifuged at $4^{\circ} \mathrm{C}$ and $440 \mathrm{~g}$ (iCEN-24, Allsheng, Hangzhou, Zhejiang, China). The upper layer was then removed and stored at $-80^{\circ} \mathrm{C}$. The protein standard curve was drawn according to the instructions of the BCA Protein Concentration Assay Kit (Thermo Fisher Scientific, Inc.), and the protein concentration in the sample was measured from the standard curves. The amount of protein was mixed with $2 \times$, and $12 \%$ SDSPAGE (Thermo Fisher Scientific, Inc.) gel electrophoresis $(140 \mathrm{~V}, 2 \mathrm{~h})$ was carried out. Proteins were transferred onto a nitrocellulose membrane $\left(4^{\circ} \mathrm{C}, 100 \mathrm{~mA}, 1 \mathrm{~h}\right)$ and blocked (5\% skim milk at $25^{\circ} \mathrm{C}$ shaker $1 \mathrm{~h}$ ). After incubation with TBST three times for 10 min each, the membrane was kept overnight at $4^{\circ} \mathrm{C}$. The membrane was then incubated at $25^{\circ} \mathrm{C}$

Table 1. Sequences of Reverse Transcription-Polymerase Chain Reaction Primers Used in this Study

\begin{tabular}{ll}
\hline Gene name & \multicolumn{1}{c}{ Sequence } \\
\hline c-Kit & Forward: 5'-AGA CCG AAC GCA ACT-3' \\
& Reverse: 5'-GGT GCC ATC CAC TTC A-3' \\
SCF & Forward: 5'-AAA CTG GTG GCG AAT-3' \\
& Reverse: 5'-CAC GGG TAG CAA GAA-3' \\
TRPV1 & Forward: 5'-AGC GAG TTC AAA GAC-3' \\
& Reverse: 5'-TTC TCC ACC AAG AGG-3' \\
GDNF & Forward: 5'-TTT TAT TCA AGC CAC CAT-3' \\
& Reverse: 5'-AGC CCA AAC CCA AGT-3' \\
NOS & Forward: 5'-CCA CAT CTG GCA GGA-3' \\
& Reverse: 5'-AGG CAC AGA ACT GAG-3' \\
GAPDH & Forward: 5'-CGG AGT CAA CGG ATT-3' \\
& Reverse: 5'-AGC CTT CTC CAT GGT-3' \\
\hline
\end{tabular}

SCF, stem cell factor; TRPV1, transient receptor potential cation channel subfamily V member 1; GDNF, glial cell-derived neurotrophic factor; NOS, nitric oxide synthase; GAPDH, glyceraldehyde-3-phosphate dehydrogenase. for $2 \mathrm{~h}$ with secondary antibody and then washed three times with TBST for $10 \mathrm{~min}$. Finally, the gray value of each group was compared. ${ }^{9}$

\section{Data analysis}

The results of three parallel repeated experiments were averaged. SAS9.1 software was used to analyze significant differences in the data of each group at $P<.05$ level by using one-way ANOVA.

\section{RESULTS}

\section{Acid and bile salt resistance of LP-YS3}

In vitro experiments showed that LP-YS3 had better survivability in artificial gastric juice $(\mathrm{pH} 3)$ and stronger growth in bile salt than LB (Table 2). Specifically, survivability of LP-YS3 in artificial gastric juice ( $\mathrm{pH} 3$ ) was $72.38 \%$, which was three times greater than that of LB $(23.87 \%)$. Growth of LP-YS3 in $1.0 \%$ bile salt $(11.02 \%)$ was also higher than that of LB (1.13\%). On the whole, the acid and bile salt resistance abilities of LP-YS3 were better than those of commercial lactic acid bacteria LB, LP-YS3 had the better potential for use as a probiotic than LB.

\section{Body weights of LP-YS3 treated mice}

Body weights of mice significantly changed $(P<.05)$ between days 1 and 14 (Fig. 1). Activated carbon treatment induced body weight reduction in mice. Control mice showed the lowest body weight, whereas LB and LP-YS3 treatments prevented loss of body weight. Body weight of mice treated with high concentrations of LP-YS3 (LP-YS3$\mathrm{H})$ were similar to that of normal mice. The constipation induced by activated carbon resulted in the loss of weight in mice, and LP-YS3 could alleviate the loss of weight, and the effect was better than that of LB.

\section{Stool status of LP-YS3 treated mice}

Stool weight, number of stool particles, and water content of stool were significantly different among the different groups of mice from days 1 to 14 (Table 3 ). Following induction of constipation by activated carbon, control mice showed the lowest stool weight, stool particle counts, and water content of stool. On the other hand, LP-YS3-H elevated all three stool parameters in comparison to control

Table 2. Acid and Bile Salt Resistance Activities of LACTOBACILLUS PLANTARUM YS3 AND LACTOBACILLUS BULGARICUS

\begin{tabular}{lcrrr}
\hline & \multirow{2}{*}{$\begin{array}{c}\text { Survival in } \\
\text { pH 3.0 artificial }\end{array}$} & \multicolumn{3}{c}{ Growth in bile salt (\%) } \\
\cline { 3 - 5 } Strain & gastric juice (\%) & \multicolumn{1}{c}{$0.3 \%$} & $0.5 \%$ & $1.0 \%$ \\
\hline LP-YS3 & $72.38 \pm 7.62$ & $19.33 \pm 1.28$ & $16.82 \pm 2.68$ & $11.02 \pm 1.89$ \\
LB & $23.87 \pm 4.25$ & $2.28 \pm 0.58$ & $1.52 \pm 0.44$ & $1.13 \pm 0.21$ \\
\hline
\end{tabular}

Values presented are the mean \pm standard deviation.

LP-YS3, Lactobacillus plantarum YS3; LB, Lactobacillus bulgaricus. 


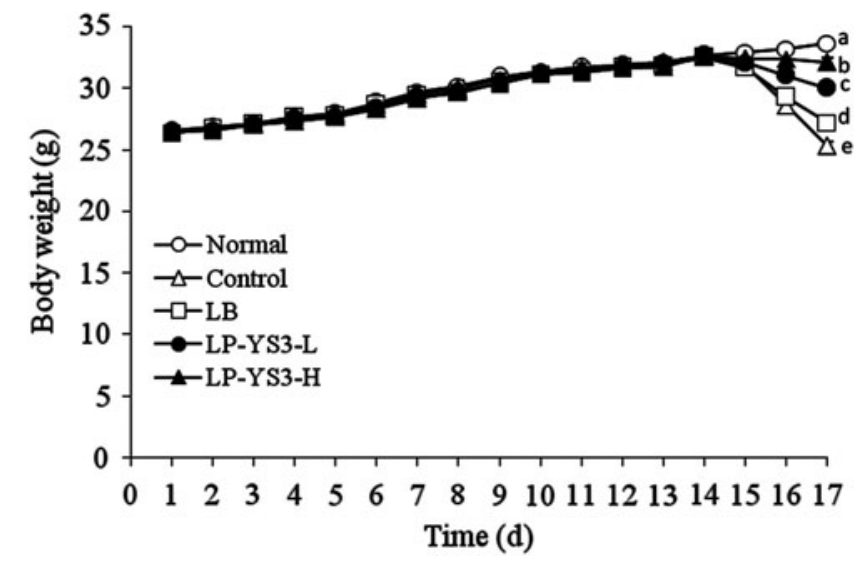

FIG. 1. Effects of Lactobacillus bulgaricus and Lactobacillus plantarum YS3 on body weight changes in activated carbon-induced constipated mice during the experiment $(N=10 /$ group $) .{ }^{\mathrm{a}-\mathrm{e}}$ Mean values with different letters over the bars are significantly different $(P<.05)$ according to Duncan's multiple-range test. LB: L. bulgaricus $\left(1.0 \times 10^{9} \mathrm{CFUs} / \mathrm{kg}\right.$ bw); LP-YS3-L: L. plantarum YS3 low dose $\left(1.0 \times 10^{8} \mathrm{CFU} / \mathrm{kg}\right.$ bw); LP-YS2-H: L. plantarum YS3 high dose $\left(1.0 \times 10^{9} \mathrm{CFU} / \mathrm{kg} \mathrm{bw}\right)$. BW, body weight; $\mathrm{CFU}$, colony-forming unit.

mice. Moreover, LP-YS3-H provided better results than the same concentration of LB and low concentration of LP-YS3 (LP-YS3-L) but slightly worse results compared to normal mice. Constipation led to abnormality of feces, and LP-YS3 could normalize the excrement of the constipated mice, and was more effective than in the LB treated mice.

\section{Initial black stool defecation time of LP-YS3 treated mice}

On the last day of the animal experiment, all mice were treated with activated carbon. Initial black stool defecation times of mice in the normal, control, LB, LP-YS3-L, and LP-YS3-H groups were $83 \pm 9 \mathrm{~min}, 195 \pm 28 \mathrm{~min}$, $163 \pm 22 \mathrm{~min}, 147 \pm 26 \mathrm{~min}$, and $112 \pm 19 \mathrm{~min}$, respectively (Fig. 2). Initial black stool defecation time was reduced in mice treated with LP-YS3 compared with control mice, and LP-YS3-H showed the best results overall. Constipation led to difficulty in defecation and increased the time of the mice to discharge the initial black stool excretion. LP-YS3 could reduce the time of the constipated mice to discharge the initial black stool excretion, and the effect was better than that of LB.

\section{GI transit capability of LP-YS3 treated mice}

After activated carbon treatment for $30 \mathrm{~min}$, control constipated mice showed the longest GI transit time. Mice in the LB and LP-YS3 groups showed faster GI transit times (Table 4). Regarding overall GI and small intestinal transit times, normal mice showed the fastest transit time based on activated carbon propulsive rate. Transit times of the LPYS3-H, LP-YS3-L, and LB groups declined, indicating faster propulsive rates, compared with that of control mice. Activated carbon induced constipation could slow down the actions of activated carbon in the small intestine, and the residence time of activated carbon in the small intestine is long. LP-YS3 could accelerate the GI of activated carbon in the small intestine, and the effect was better than LB.

\section{Serum levels of LP-YS3 treated mice}

As shown in Table 5, serum levels of MTL, Gas, ET, AChE, SP, and VIP in control mice were the lowest. On the contrary, serum levels of these parameters in normal mice were the highest. LB and LP-YS3 group mice showed increased levels of MTL, Gas, ET, AChE, SP, and VIP in addition to reduced SS levels compared with control mice. Meanwhile, LP-YS3-H treated mice showed remarkable increases in MTL, Gas, ET, AChE, SP, and VIP levels almost up to those of normal mice. Mice in the LP-YS3-H group also showed a weak SS level, which was slightly stronger than that of normal mice.

\section{Small intestine tissue levels of LP-YS3 treated mice}

As shown in Table 6, normal mice showed the lowest MPO, NO, and MDA intestine tissue levels and the highest GSH level. On the contrary, control mice had the highest MPO, NO, and MDA levels and lowest GSH level. LB and LP-YS3 group mice showed increased GSH levels and reduced MPO, NO, and MDA levels compared with control mice, and LP-YS3-H treatment showed the strongest effects.

Table 3. Stool Status of Lactic Acid Bacteria Treated Mice During the Experiment

\begin{tabular}{|c|c|c|c|c|c|}
\hline Groups & Normal & Control & $L B$ & $L P-Y S 3-L$ & $L P-Y S 3-H$ \\
\hline \multicolumn{6}{|c|}{ 1-14 days (lactic acid bacteria administration period, but not induction of constipation) } \\
\hline Stool weight $(\mathrm{g})$ & $0.92 \pm 0.05^{\mathrm{a}}$ & $0.92 \pm 0.05^{\mathrm{a}}$ & $0.91 \pm 0.04^{\mathrm{a}}$ & $0.92 \pm 0.05^{\mathrm{a}}$ & $0.92 \pm 0.05^{\mathrm{a}}$ \\
\hline Particle counts of stool & $39 \pm 3^{\mathrm{a}}$ & $39 \pm 4^{\mathrm{a}}$ & $40 \pm 4^{\mathrm{a}}$ & $40 \pm 3^{\mathrm{a}}$ & $40 \pm 3^{\mathrm{a}}$ \\
\hline Water content of stool $(\%)$ & $48 \pm 4^{\mathrm{a}}$ & $48 \pm 3^{\mathrm{a}}$ & $49 \pm 4^{\mathrm{a}}$ & $49 \pm 3^{\mathrm{a}}$ & $50 \pm 4^{\mathrm{a}}$ \\
\hline \multicolumn{6}{|c|}{ 15-17 days (lactic acid bacteria administration period, induction of constipation) } \\
\hline Stool weight $(\mathrm{g})$ & $0.96 \pm 0.04^{\mathrm{a}}$ & $0.43 \pm 0.05^{\mathrm{d}}$ & $0.62 \pm 0.05^{\mathrm{c}, \mathrm{d}}$ & $0.64 \pm 0.05^{\mathrm{c}}$ & $0.76 \pm 0.05^{\mathrm{b}}$ \\
\hline Particle counts of stool & $40 \pm 5^{\mathrm{a}}$ & $22 \pm 2^{\mathrm{d}}$ & $27 \pm 3^{c}$ & $29 \pm 4^{\mathrm{b}, \mathrm{c}}$ & $33 \pm 4^{\mathrm{b}}$ \\
\hline Water content of stool $(\%)$ & $49 \pm 5^{\mathrm{a}}$ & $17 \pm 4^{\mathrm{d}}$ & $32 \pm 4^{\mathrm{c}}$ & $34 \pm 4^{\mathrm{b}, \mathrm{c}}$ & $41 \pm 4^{\mathrm{b}}$ \\
\hline
\end{tabular}

Values presented are the mean \pm standard deviation ( $N=10$ /group).

${ }^{\mathrm{a}-\mathrm{d}}$ Mean values with different letters in the same row are significantly different $(P<.05)$ according to Duncan's multiple-range test. LB: L. bulgaricus $\left(1.0 \times 10^{9}\right.$ CFUs/kg bw); LP-YS3-L: L. plantarum YS3 low dose $\left(1.0 \times 10^{8} \mathrm{CFU} / \mathrm{kg}\right.$ bw); LP-YS3-H: L. plantarum YS3 high dose $\left(1.0 \times 10^{9} \mathrm{CFU} / \mathrm{kg}\right.$ bw).

$\mathrm{BW}$, body weight; $\mathrm{CFU}$, colony-forming unit. 


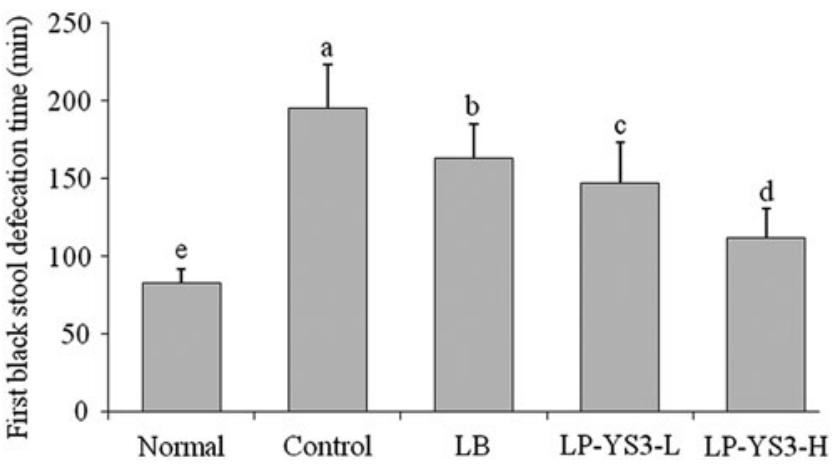

FIG. 2. Initial black stool defecation time in $L$. bulgaricus and $L$. plantarum YS3 treated activated carbon-induced constipated mice. ${ }^{\text {a- }}$ ${ }^{\mathrm{e}}$ Mean values with different letters over the bars are significantly different $(P<.05)$ according to Duncan's multiple-range test. LB: $L$. bulgaricus $\left(1.0 \times 10^{9} \mathrm{CFUs} / \mathrm{kg}\right.$ bw); LP-YS3-L: L. plantarum YS3 low dose $\left(1.0 \times 10^{8} \mathrm{CFU} / \mathrm{kg}\right.$ bw); LP-YS2-H: L. plantarum YS3 high dose $\left(1.0 \times 10^{9} \mathrm{CFU} / \mathrm{kg}\right.$ bw $)$.

\section{Pathological observations in small intestine}

Mice in the normal group showed homogenous small intestinal wall thickness and complete small intestinal villi. On the other hand, small intestinal villi in control mice were all injured and impaired, and thickness of the small intestinal wall was heterogeneous. The LB group mice showed a reversal of villi injury and impairment and reduced heterogeneity of the small intestinal wall. The protective effects of LP-YS3 in the small intestine were greater than those of LB. These effects were further enhanced by LP-YS3-H and were slightly stronger than that of LP-YS3-L (Fig. 3).

\section{c-Kit and SCF mRNA and protein expression levels in small intestine tissue}

As shown in Figure 4, small intestinal tissue from normal mice showed the highest c-Kit $(9.49 \pm 0.42$ and $1.91 \pm 0.12$ folds of control) and SCF (9.37 \pm 0.45 and $2.42 \pm 0.19$-folds of control) mRNA and protein expression levels, whereas control mice showed the weakest expression. LB and LPYS3 treatments enhanced c-Kit and SCF expression in comparison to untreated control mice. Lastly, LP-YS3-H significantly enhanced c-Kit (7.24 \pm 0.33 and $1.69 \pm 0.11-$ folds greater than control) and SCF (7.01 \pm 0.53 and $2.03 \pm$ 0.17 -folds greater than control) expression levels almost up to those of the normal group.

\section{TRPVI, GDNF, and NOS mRNA and protein expression levels in small intestine tissue}

As shown in Figure 5, normal mice showed the strongest GDNF (5.77 \pm 0.51 and $2.32 \pm 0.32$-folds higher than control) mRNA and protein expression along with the weakest TRPV1 $(0.16 \pm 0.03$ and $0.57 \pm 0.05$-folds of control $)$ and NOS $(0.24 \pm 0.04$ and $0.57 \pm 0.05$-folds of control) expression in the small intestine. LB, LP-YS3-L, and LP-YS3-H treatments elevated GDNF expression and reduced TRPV1 and NOS expression in small intestinal tissue compared with control mice. Lastly, LP-YS3-H treatment elevated TRPV1 $(0.38 \pm 0.03$ and $0.66 \pm 0.05$-folds of control), $\operatorname{GDNF}(4.21 \pm$ 0.31 and $1.93 \pm 0.22$-folds of control), and NOS $(0.33 \pm 0.05$ and $0.62 \pm 0.05$-folds of control) expression levels almost up to those of normal mice.

\section{DISCUSSION}

Lactobacillus play a probiotic role and show physiological function in the strong bile acid environment of the stomach and intestine. ${ }^{10}$ Here, we studied the potential probiotic effects of lactic acid bacteria by establishing an in vitro virtual model, which is a common method to detect the antigastric acid activity and bile salt tolerance of lactic acid bacteria. ${ }^{11}$ We observed that LP-YS3 had stronger antigastric activity acid and bile salt tolerance than LB, which has good physiological activity.

Body weight change is an important indicator of constipation in mice, and our study as well as many other
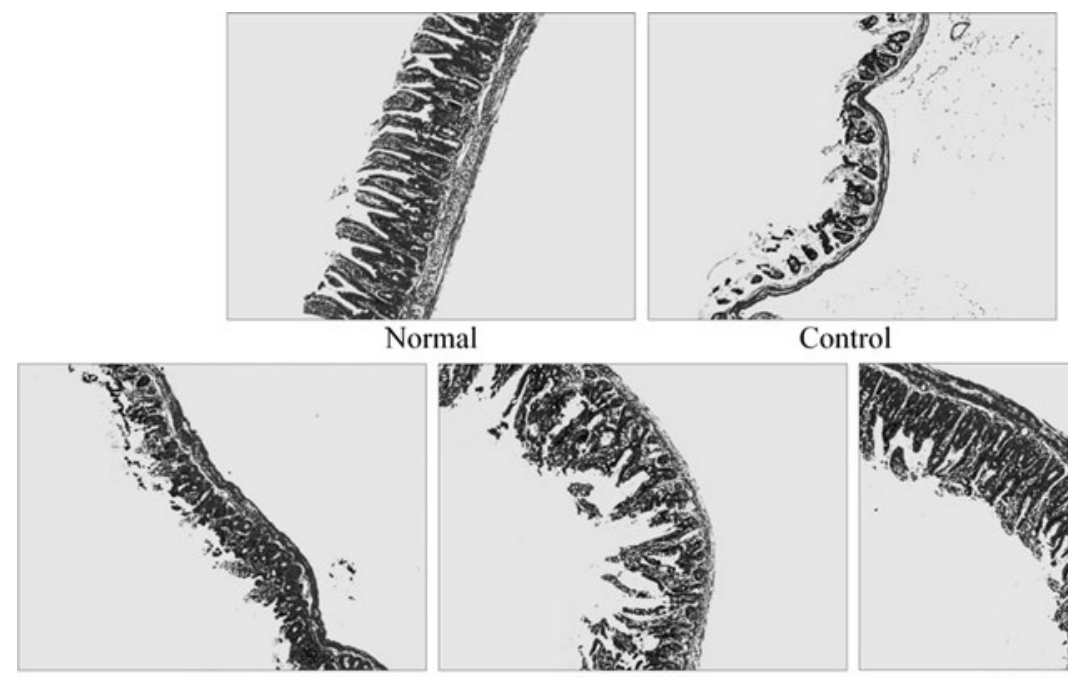

LB

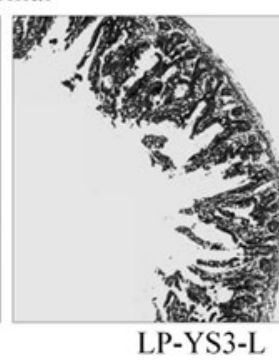

LP-YS3-L
Control

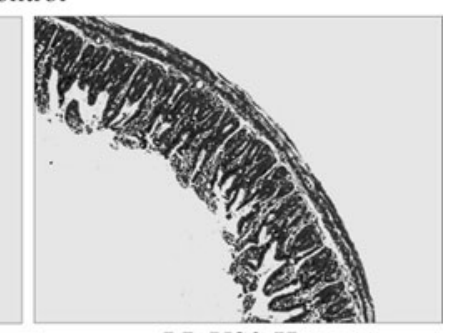

LP-YS3-H
FIG. 3. Pathological observation of small intestine tissue in L. bulgaricus and $L$. plantarum YS3 treated activated carbon-induced constipated mice. LB: L. bulgaricus $\left(1.0 \times 10^{9} \mathrm{CFUs} / \mathrm{kg}\right.$ bw); LP-YS3-L: L. plantarum YS3 low dose $\left(1.0 \times 10^{8} \mathrm{CFU} / \mathrm{kg}\right.$ bw); LP-YS2-H: $L$. plantarum YS3 high dose $\left(1.0 \times 10^{9}\right.$ CFU/kg bw). 
Table 4. Gastrointestinal Transit Capability and First Black Stool Defection Time in Lactobacillus bulgaricus AND LACTOBACILLUS PLANTARUM YS3 TREATED ACTIVATED Carbon-Induced Constipated Mice

\begin{tabular}{lccc}
\hline & $\begin{array}{c}\text { Length of } \\
\text { small } \\
\text { Groups }\end{array}$ & $\begin{array}{c}\text { Length of } \\
\text { intestine }(\mathrm{cm})\end{array}$ & $\begin{array}{c}\text { Activated carbon } \\
\text { Gropulsive rate (\%) }\end{array}$ \\
\hline Normal & $41.2 \pm 4.0^{\mathrm{a}}$ & $39.2 \pm 4.1^{\mathrm{a}}$ & $95.1 \pm 1.1^{\mathrm{a}}$ \\
Control & $40.3 \pm 3.9^{\mathrm{a}}$ & $6.3 \pm 1.2^{\mathrm{e}}$ & $15.6 \pm 2.2^{\mathrm{e}}$ \\
LB & $40.8 \pm 4.3^{\mathrm{a}}$ & $23.8 \pm 2.2^{\mathrm{d}}$ & $58.3 \pm 2.4^{\mathrm{d}}$ \\
LP-YS3-L & $40.8 \pm 4.5^{\mathrm{a}}$ & $28.3 \pm 1.9^{\mathrm{c}}$ & $69.4 \pm 2.5^{\mathrm{c}}$ \\
LP-YS3-H & $40.9 \pm 4.1^{\mathrm{a}}$ & $31.2 \pm 2.5^{\mathrm{b}}$ & $76.3 \pm 2.2^{\mathrm{b}}$ \\
\hline
\end{tabular}

Values presented are the mean \pm standard deviation $(N=10$ /group $)$.

${ }^{a-e}$ Mean values with different letters in the same column are significantly different $(P<.05)$ according to Duncan's multiple-range test. LB: $L$. bulgaricus $\left(1.0 \times 10^{9} \mathrm{CFU} / \mathrm{kg}\right.$ bw); LP-YS3-L: L. plantarum YS3 low dose $\left(1.0 \times 10^{8} \mathrm{CFU} / \mathrm{kg}\right.$ bw); LP-YS3-H: L. plantarum YS3 high dose $\left(1.0 \times 10^{9}\right.$ $\mathrm{CFU} / \mathrm{kg}$ bw).

GI, gastrointestinal.

studies have shown that mice with active carbon-induced constipation weigh less than health mice. ${ }^{12}$ For instance, hydrochloric acid amine-induced constipation in mice can lead to body weight loss in mice. ${ }^{13}$ Our study results corroborate literature reports that animal constipation can lead to weight loss, as LP-YS3 showed the greatest inhibitory effects against weight loss caused by constipation.

Stool quality, fecal grains, and fecal water content are important indicators of fecal status and reflect an aggravated degree of constipation when low. ${ }^{12}$ Many studies have shown that lactic acid bacteria can improve fecal particle number and water content in constipated mice. ${ }^{13,14}$ In this study, the lactic acid bacterium LP-YS3 relieved constipation by improving defecation quality, defecation times, and water content in mice feces.

Constipation can reduce bowel motility and increase fecal transit time, leading to the accumulation of harmful bacteria that feed on fecal matter and thereby threatening intestinal health. ${ }^{15}$ Propelling length and propulsive rate of the small intestine can be used to evaluate intestinal activity and constipation in activated carbon-induced constipated mice. ${ }^{6}$
In this study, LP-YS3 reduced the amount of activated carbon in the small intestine of mice, and propulsive rate and length were higher than those of LB mice. The effects of LPYS3-H were even more obvious.

In terms of establishing an animal model of constipation, mice were chosen since they are less tolerant than rats. According to Chinese medicine, obstruction of air caused by cold temperatures can induce constipation in mice in a manner similar to activated carbon water. ${ }^{16}$ Constipation causes retardation of intestinal movement and longer fecal retention times, thereby enlarging initial black stool discharge. ${ }^{6}$ A shorter initial black stool excretion time indicates normal intestinal movements. In this study, LP-YS3 could reduce the initial black stool excretion time, and the effect stronger than LB.

MTL is known to stimulate pepsin production and promote intestinal motility. ${ }^{17}$ Gas plays an important role in the GI tract, as it can promote GI secretion, motility, pyloric relaxation, and relief of constipation. ${ }^{6}$ ET plays an important role in vascular tone stability and maintenance of the basic cardiovascular system. ${ }^{18}$ SS is used to stimulate bowel movements. ${ }^{19}$ AChE promotes muscle contraction and mucus secretion, resulting in muscle relaxation and fecal excretion. ${ }^{20} \mathrm{SP}$ also promotes intestinal peristalsis, ${ }^{21}$ maintaining normal levels of VIP in the intestinal wall as an important means of stabilizing gut function. ${ }^{22}$ The collective effects of these factors ease constipation. The results of this study show that LP-YS3 normalizes serum levels of these factors and relieves constipation.

Interstitial cells of Cajal (ICC) are slow wave pacemaker cells in the gut and play an important role in enteric nerve signaling. Indeed, ICC affect GI function. ${ }^{23}$ Research has shown that ICC from patients with intestinal constipation have lower density than normal ICC. This causes responses that decrease the availability of neurotransmitters, resulting in spontaneous rhythmic slow wave loss and leading to irregular colonic motility and intestinal functional effects. ${ }^{23-25}$ c-Kit is a specific marker of ICC and a key factor in the proliferation of ICC. ${ }^{26} \mathrm{SCF}$ concentration is important for ICC production, as ICC do not grow in the absence of SCF. Animal experiments have shown that the ICC content of colon tissue from constipated mice is very low, and the

Table 5. Serum Levels of MTL, GAS, ET, SS, AcHE, SP, and VIP in LaCtobacillus bulgaricus and Lactobacillus plantarum YS3 Treated Activated Carbon-Induced Constipated Mice

\begin{tabular}{|c|c|c|c|c|c|}
\hline Levels $(\mathrm{pg} / \mathrm{mL})$ & Normal & Control & $L B$ & $L P-Y S 3-L$ & $L P-Y S 3-H$ \\
\hline MTL & $217.8 \pm 17.8^{\mathrm{a}}$ & $87.0 \pm 7.9^{\mathrm{e}}$ & $132.3 \pm 12.1^{\mathrm{d}}$ & $152.7 \pm 13.2^{\mathrm{c}}$ & $187.2 \pm 9.3^{\mathrm{b}}$ \\
\hline Gas & $93.2 \pm 5.1^{\mathrm{a}}$ & $30.8 \pm 3.3^{\mathrm{e}}$ & $49.8 \pm 2.9^{\mathrm{d}}$ & $60.3 \pm 2.5^{c}$ & $71.3 \pm 2.8^{\mathrm{b}}$ \\
\hline ET & $19.3 \pm 1.3^{\mathrm{a}}$ & $4.1 \pm 0.6^{\mathrm{e}}$ & $7.0 \pm 0.4^{\mathrm{d}}$ & $8.9 \pm 0.7^{\mathrm{c}}$ & $13.5 \pm 0.8^{\mathrm{b}}$ \\
\hline SS & $26.3 \pm 2.8^{\mathrm{e}}$ & $71.3 \pm 3.8^{\mathrm{a}}$ & $55.9 \pm 2.9^{\mathrm{b}}$ & $40.8 \pm 2.2^{\mathrm{c}}$ & $33.5 \pm 1.1^{\mathrm{d}}$ \\
\hline $\mathrm{AChE}$ & $39.2 \pm 1.5^{\mathrm{a}}$ & $8.3 \pm 0.5^{\mathrm{e}}$ & $14.5 \pm 0.6^{\mathrm{d}}$ & $24.2 \pm 0.7^{\mathrm{c}}$ & $31.2 \pm 1.4^{\mathrm{b}}$ \\
\hline SP & $73.2 \pm 2.6^{\mathrm{a}}$ & $28.3 \pm 2.2^{\mathrm{e}}$ & $50.3 \pm 2.5^{\mathrm{d}}$ & $59.3 \pm 1.5^{\mathrm{c}}$ & $66.3 \pm 2.7^{b}$ \\
\hline VIP & $65.3 \pm 2.1^{\mathrm{a}}$ & $24.6 \pm 2.3^{\mathrm{e}}$ & $40.3 \pm 2.6^{\mathrm{d}}$ & $48.3 \pm 2.1^{\mathrm{c}}$ & $58.3 \pm 1.9^{\mathrm{b}}$ \\
\hline
\end{tabular}

Values presented are the mean \pm standard deviation ( $N=10 /$ group).

${ }^{\mathrm{a}-\mathrm{e}}$ Mean values with different letters in the same row are significantly different $(P<.05)$ according to Duncan's multiple-range test. LB: $L$. bulgaricus $\left(1.0 \times 10^{9}\right.$ CFU/kg bw); LP-YS3-L: L. plantarum YS3 low dose $\left(1.0 \times 10^{8}\right.$ CFU/kg bw); LP-YS3-H: L. plantarum YS3 high dose $\left(1.0 \times 10^{9} \mathrm{CFU} / \mathrm{kg}\right.$ bw).

MTL, motilin; gastrin, ET-1, endothelin; SS, somatostatin; AChE, acetylcholinesterase; SP, substance P; VIP, vasoactive intestinal peptide. 
Table 6. Small Intestine Tissue Levels of MPO, NO, GSH, and MDA in LaCtobacillus bulgaricus and Lactobacillus plantarum YS3 Treated Activated Carbon-Induced Constipated Mice

\begin{tabular}{|c|c|c|c|c|}
\hline Group & $M P O(\mathrm{mU} / \mathrm{mg})$ & NO ( $\mu \mathrm{mol} / \mathrm{gprot})$ & MDA (nmol/mg) & GSH $(\mu \mathrm{mol} / \mathrm{mg})$ \\
\hline Normal & $6.12 \pm 0.21^{\mathrm{d}}$ & $0.32 \pm 0.08^{\mathrm{d}}$ & $0.38 \pm 0.05^{\mathrm{d}}$ & $8.31 \pm 0.62^{\mathrm{a}}$ \\
\hline Control & $17.22 \pm 0.56^{\mathrm{a}}$ & $1.92 \pm 0.22^{\mathrm{a}}$ & $1.06 \pm 0.13^{\mathrm{a}}$ & $4.58 \pm 0.31^{\mathrm{d}}$ \\
\hline LB & $12.05 \pm 0.42^{\mathrm{b}}$ & $1.15 \pm 0.12^{\mathrm{b}}$ & $0.78 \pm 0.08^{\mathrm{b}}$ & $6.68 \pm 0.22^{\mathrm{c}}$ \\
\hline LP-YS3-L & $11.02 \pm 0.32^{\mathrm{b}}$ & $0.82 \pm 0.10^{\mathrm{b}}$ & $0.66 \pm 0.08^{\mathrm{b}}$ & $7.03 \pm 0.15^{\mathrm{c}}$ \\
\hline LP-YS3-H & $8.52 \pm 0.32^{\mathrm{c}}$ & $0.61 \pm 0.05^{\mathrm{c}}$ & $0.48 \pm 0.06^{\mathrm{c}}$ & $7.58 \pm 0.14^{\mathrm{b}}$ \\
\hline
\end{tabular}

Values presented are the mean \pm standard deviation $(N=10$ /group).

${ }^{\mathrm{a}-\mathrm{e}}$ Mean values with different letters in the same column are significantly different $(P<.05)$ according to Duncan's multiple-range test. LB: $L$. bulgaricus $\left(1.0 \times 10^{9}\right.$ CFU/kg bw); LP-YS3-L: L. plantarum YS3 low dose $\left(1.0 \times 10^{8}\right.$ CFU/kg bw); LP-YS3-H: L. plantarum YS3 high dose $\left(1.0 \times 10^{9} \mathrm{CFU} / \mathrm{kg}\right.$ bw). MPO, myeloperoxidase; NO, nitric oxide; MDA, malondialdehyde; GSH, glutathione.

expression level of c-Kit in colon tissue is also reduced. ${ }^{27}$ Another study has shown that lactic acid bacteria can effectively increase c-Kit content in the intestinal tract of constipated mice and the number of ICC, thereby promoting intestinal peristalsis and relief of constipation. ${ }^{28}$ In this study, constipation reduced the expression of c-Kit and SCF in the small intestine of mice while LP-YS3 treatment effectively upregulated expression of c-Kit and SCF, thereby increasing the number of ICC in the intestinal tracts of constipated mice and inhibiting constipation.

mRNA expression

Normal Control LB LP-YS3-L LP-YS3-H

Protein expression
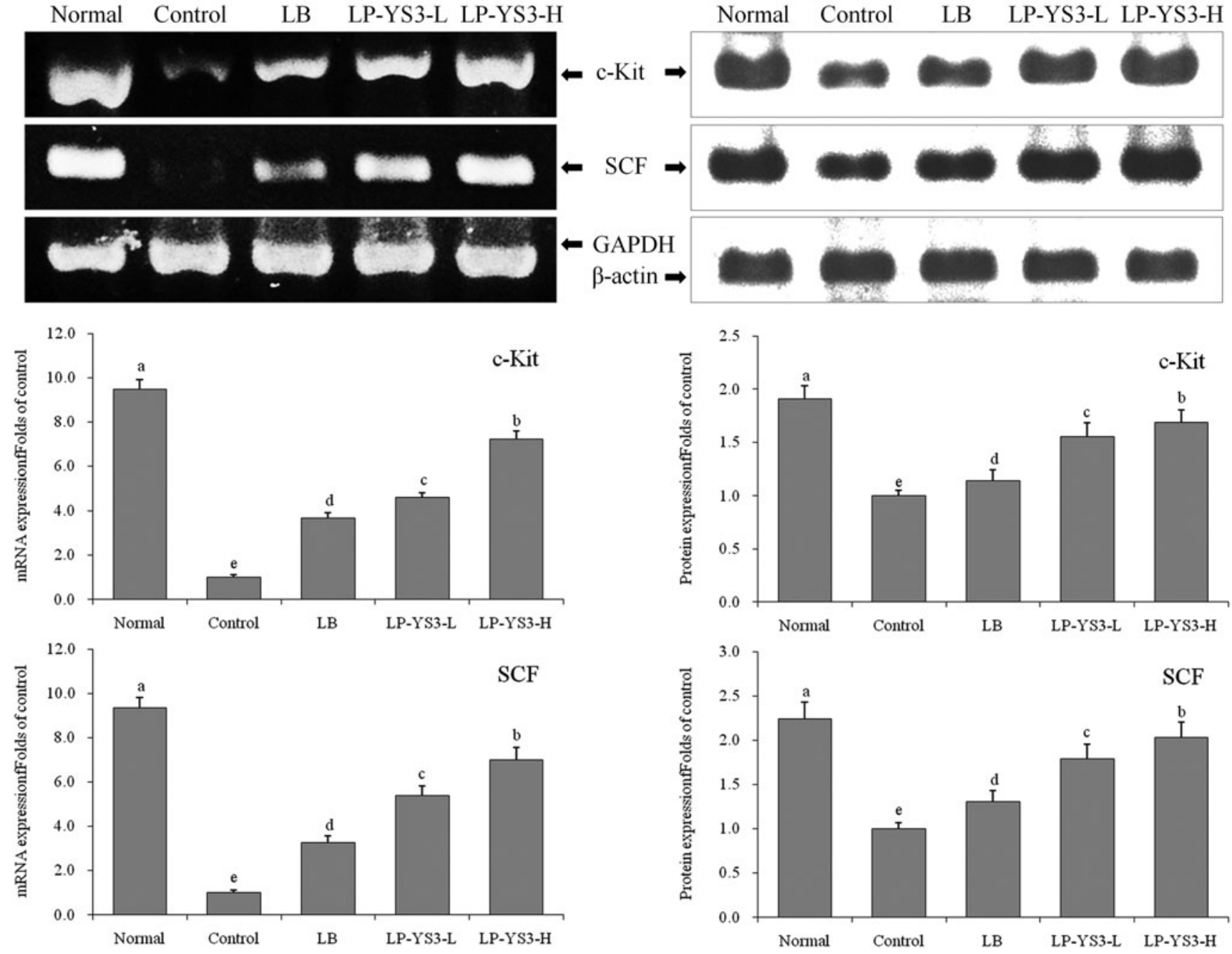

FIG. 4. Small intestine tissue mRNA and protein expression levels of c-Kit and SCF in L. bulgaricus and L. plantarum YS3 treated activated carbon-induced constipated mice. LB: L. bulgaricus $\left(1.0 \times 10^{9} \mathrm{CFUs} / \mathrm{kg}\right.$ bw); LP-YS3-L: L. plantarum YS3 low dose $\left(1.0 \times 10^{8} \mathrm{CFU} / \mathrm{kg}\right.$ bw); LPYS3-H: L. plantarum YS3 high dose $\left(1.0 \times 10^{9} \mathrm{CFU} / \mathrm{kg}\right.$ bw). SCF, stem cell factor. 

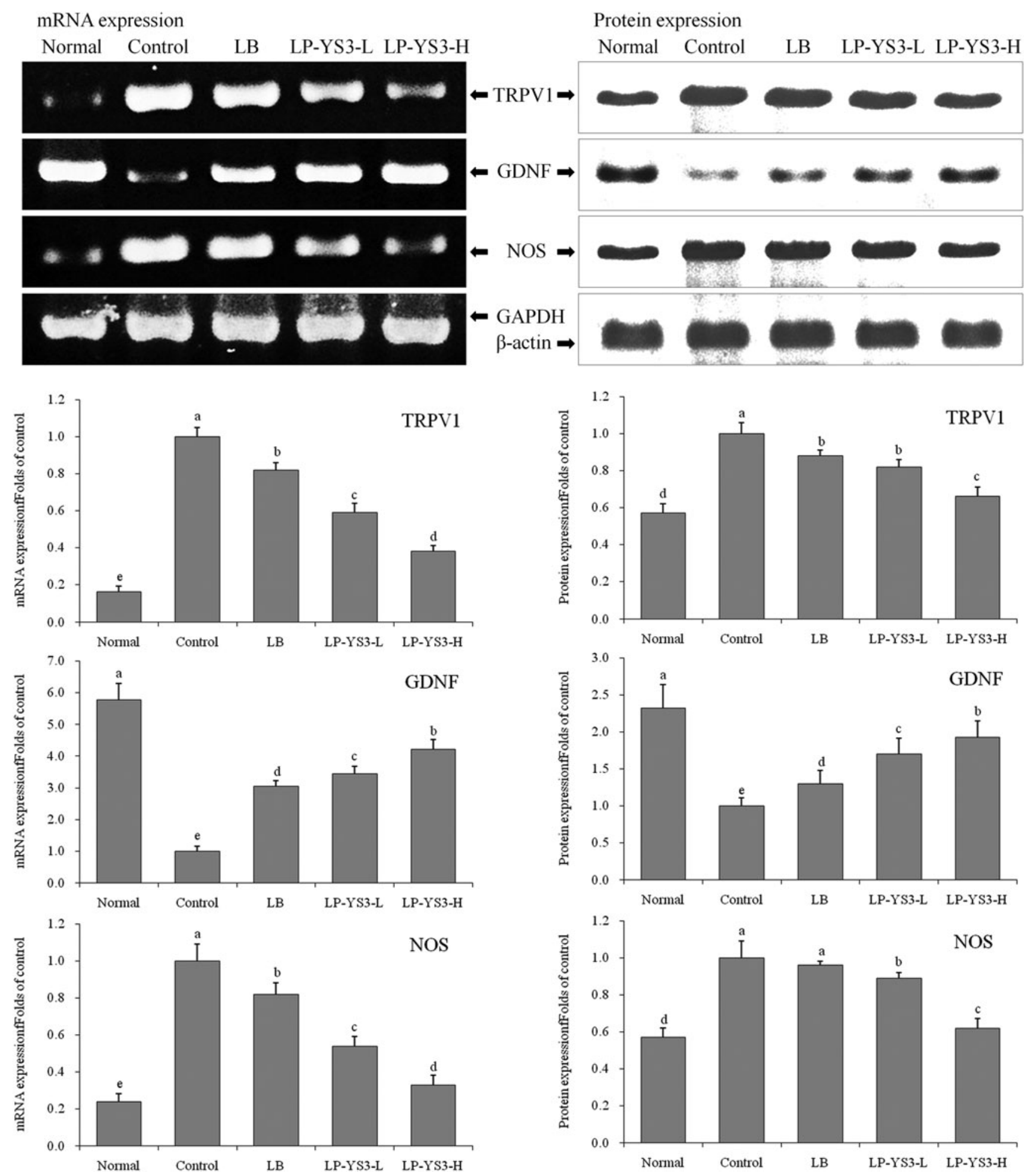

FIG. 5. Small intestine tissue mRNA and protein expression levels of TRPV1, GDNF, and NOS in the LB and LP-YS3 treated activated carboninduced constipation mice. LB: L. bulgaricus $\left(1.0 \times 10^{9} \mathrm{CFUs} / \mathrm{kg}\right.$ bw); LP-YS3-L: L. plantarum YS3 low dose $\left(1.0 \times 10^{8} \mathrm{CFU} / \mathrm{kg}\right.$ bw $)$; LP-YS3-H: L. plantarum YS3 high dose $\left(1.0 \times 10^{9} \mathrm{CFU} / \mathrm{kg}\right.$ bw). TRPV1, transient receptor potential cation channel subfamily V member 1; GDNF, glial cellderived neurotrophic factor; NOS, nitric oxide synthase. 
Constipation is more common in elderly populations. Bacteria in the human gut produce a large number of toxins such as indole and indole acetic acid, which cause chronic poisoning upon absorption into the body and aging. ${ }^{29} \mathrm{Con}-$ stipation patients cannot rule out the presence of toxic substances, as the body accumulates large amounts of toxic substances as time passes. Toxic substances accumulated in the body can overwhelm the detoxifying ability of the liver, causing toxic substances to circulate in the blood into the brain, thereby accelerating aging. MPO, NO, GSH, and MDA all are aging-related factors. ${ }^{30,31}$ In this study, LP-YS3 significantly regulated the development of aging-related factors and helped alleviate aging and constipation.

TRPV1 has been shown to be closely related with defecation. Activation of TRPV1 triggers release of neurotransmitters, leading to movement disorders in the small intestine. ${ }^{32}$ Increased expression of TRPV1 is a significant symptom of intestinal injury, and GI disturbances result in higher TRPV1 expression in patients with constipation. There is a known relationship between constipation and the enteric nervous system. NO is a major inhibitory neurotransmitter in the enteric nervous system that induces smooth muscle relaxation and reduces GI motility. An increase in the number of positive fibers of NOS leads to elevation of NO content, thus affecting intestinal function and causing constipation. ${ }^{33,34}$ NOS also plays an important role in regulating GI motility. ${ }^{35}$ Upregulation of NO causes serious colonic motility disorders, and controlling NOS could reduce the content of $\mathrm{NO}$ as a feasible means to control constipation. ${ }^{36}$ Expression of these genes in the intestinal tract and thus constipation can be relieved by regulating the expression of TRPV1, GDNF, and NOS. Collectively, these findings demonstrate one of the mechanisms by which lactic acid bacteria (LY-PS3) can suppress constipation.

The Tibetan yak yogurt lactic acid bacterium LP-YS3 has excellent antigastric acid activity and bile salt tolerance, and effectively inhibits body weight loss in mice caused by constipation and changes in fecal weight, particle number, and water content. LP-YS3 also improves the transit rate of activated carbon in the small intestine and reduces initial black defecation time. Analysis of mouse serum found that LP-YS3 improved levels of MTL, ET, SS, AChE, SP, VIP, and SS in constipated mice. RT-PCR and Western blot experiments further showed that LP-YS3 upregulated mRNA and protein expression levels of c-Kit, SCF, and GDNF and downregulated expression of TRPV1 and NOS in constipated mice. The results show that LP-YS3 can effectively relieve constipation better than the commonly used L. bulgaricus.

\section{ACKNOWLEDGMENTS}

The present research was supported by the Chongqing Research Program of Basic Research and Frontier Technology (cstc2016jcyjA0339) and the Open Fund of Beijing Advanced Innovation Center for Food Nutrition and Human Health (20161001), China.

\section{AUTHOR DISCLOSURE STATEMENT}

No competing financial interests exist.

\section{REFERENCES}

1. Wu CS, Shu C, Li J, Qian Y, Suo HY: The research progress and prospect of yak yogurt lactic acid bacteria. Food Ind 2012;2012: 135-139.

2. Wu CS, Li J, Qian Y, Suo HY: Research progress of yak milk and fermented yak milk and their nutritional value. J Dairy Sci Technol 2012;35:43-46.

3. Ueki A, Otsuka M: Life style risks of Parkinson's disease: Association between decreased water intake and constipation. $J$ Neurol 2004;251:18-23.

4. Qian Y, Suo HY, Du MY, Zhao X, Li J, Li GJ, et al:: Preventive effect of Lactobacillus fermentum Lee on activated carboninduced constipation in mice. Exp Ther Med 2015;61:272-278.

5. Zhao X, Suo HY, Qian Y, Li GJ, Liu ZH, Li J: Therapeutic effects of Lactobacillus casei Qian treatment in activated carbon induced constipated mice. Mol Med Rep 2015;12:3191-3199.

6. Suo HY, Zhao X, Qian Y, et al.: Therapeutic effect of activated carbon-induced constipation mice with Lactobacillus fermentum Suo on treatment. Int J Mol Sci 2014;15:21875-21895.

7. Chen XY, Li J, Zhao X, et al:: In vitro screening of lactic acid bacteria with probiotic properties from traditional fermented yak yogurt. Food Ferment Ind 2016;42:85-90.

8. Zhao X, Wang Q, Li GJ, Chen F, Qian Y, Wang R: In vitro antioxidant, anti-mutagenic, anti-cancer and anti-angiogenic effects of Chinese Bowl tea. J Func Food 2014;7:590-598.

9. Zhao X, Kim SY, Park KY: Bamboo salt has in vitro anticancer activity in HCT-116 cells and exerts anti-metastatic effects in vivo. J Med Food 2013;16:9-19.

10. Mercenier A, Pavan S, Pot B: Probiotics as biotherapeutic agents: Present knowledge and future prospects. Curr Pharm Design 2003;9:175-191.

11. Zhao WJ, Lv JL, Ma Q, Li Y: Analysis of the surface hydrophobicity of Lactobacillus acidophilus. China Dairy Ind 2011; 39:8-11.

12. Qian Y, Zhao X, Kan JQ: Preventive effect of resistant starch on activated carbon-induced constipation in mice. Exp Ther Med 2013;6:228-232.

13. Peng ZR, Liu XM, Ni XQ, et al:: Effect of Lactobacillus plantarum F1208 on gastrointestinal functions in constipated rats. Food Sci 2013;34:243-246.

14. Zhao XD, Liu AP, Zhang M, Guo HY, Ren FZ: Laxative effect of Lactobacillus paracasei subsp. paracasei LC-01 in constipated mice. J Dairy Sci Technol 2012;35:7-11.

15. Gibson GR, Roberfroid MB: Dietary modulation of the human colonic microbiota: Updating the concept of prebiotics. Nutr Res Rev 2004;125:1401-1412.

16. Liu JR, Ji YB, Chen MC: Advances of pharmacological researches in constipation animal model. Chin J Exp Tradit Med Formulae 2012;18:353-356.

17. Feighner SD, Tan CP, McKee KK, et al.: Receptor for motilin identified in the human gastrointestinal system. Science 1999; 284:2184-2188.

18. Preston DM, Adrian TE, Christofides ND, Lennard-Jones JE, Bloom SR: Positive correlation between symptoms and circulating motilin, pancreatic polypeptide and gastrin concentrations in functional bowel disorders. Gut 1985;26:1059-1064. 
19. Soudah HC, Hasler WL, Owyang C: Effect of octreotide on intestinal motility and bacterial overgrowth in scleroderma. New Eng J Med 1991;325:1461-1467.

20. Furchgott RF, Zawadzki JV: The obligatory role of endothelial cells in the relaxation of arterial smooth muscle by acetylcholine. Nature 1980;288:373-376.

21. Tzavella K, Riepl RL, Klauser AG, Voderholzer WA, Schindlbeck NE, Müller-Lissner SA: Decreased substance P levels in rectal biopsies from patients with slow transit constipation. Eur $J$ Gastroenterol Hepatol 1996;8:62-63.

22. Milner P, Crowe R, Kamm MA, Lennard-Jones JE, Burnstock G: Vasoactive intestinal polypeptide levels in sigmoid colon in idiopathic constipation and diverticular disease. Gastroenterology 1990;99:666-675.

23. Zheng Q, Xu H, Bi SY: The c-kit gene expression in gastrointestinal tract of slow transit constipation model rats. Chin $J$ Gastroenterol Hepatol 2013;22:570-574.

24. Lyford GL, He CL, Soffer E, et al:: Pan-colonic decrease in interstitial cells of Cajal in patients with slow transit constipation. Gut 2002;51:496-501.

25. Salmhofer H, Neuhuber WL, Ruth P, Huber A, Russwurm M, Allescher HD: Pivotal role of the interstitial cells of Cajal in the nitric oxide signaling pathway of rat small intestine. Cell Tissue Res 2001;305:331-340.

26. Farrugia G: Interstitial cells of Cajal in health and disease. Neurogastroenterol Motil 2008;20:54-63.

27. Brading AF, Mccloskey KD: Mechanisms of disease: Specialized interstitial cells of the urinary tract-an assessment of current knowledge. Nat Clin Pract Urol 2005;2:546-554.
28. Cao YQ, Zhang J, Zheng Z, et al:: Therapeutic effect of Lactobacillus paracasei $\mathrm{N} 1115$ fermented milk in constipated mouse. Food Sci 2018;39:185-191.

29. Kojima R, Nozawa K, Doihara H, et al.: Effects of novel TRPA1 receptor agonist ASP7663 in models of drug-induced constipation and visceral pain. Eur J Pharmacol 2014;723:288-293.

30. Zhu F, Qian J, Pan G: Application of IL-1 beta and 8 mRNA and some other indices in monitoring the activity of ulcerative colitis. Zhongguo Yi Xue Ke Xиe Yuan Xue Bao 1999;21:384-389.

31. Wang YS, Zhou P, Liu H, et al.: Effects of inulin supplementation in low- or high-fat diets on reproductive performance of sows and antioxidant defence capacity in sows and offspring. Reprod Domest Anim 2016;51:492-500.

32. Geppetti P, Trevisani M: Activation and sensitisation of the vanilloid receptor: Role in gastrointestinal inflammation and function. Br J Pharmacol 2004;141:1313-1320.

33. Meng P, Yin JK, Gao XJ, Liu P, Wang F, Wang J: The influence of Atractylodes macrocephala koidz on the level of NO and NOS in slow transmission constipation rats colonic mucosa. J Jiangxi Univ TCM 2012;24:61-63.

34. Shah V, Lyford G, Gores G, Farrugia G: Nitric oxide in gastrointestinal health and disease. Gastroenterology 2004;126: 903-913.

35. Xu GP, Fan YH, Lv B: Advances in understanding the role of neurotrophins in physiological and pathological processes in the intestinal tract. World Chin J Digestol 2010;18:2884-2888.

36. Tomita R, Igarashi S, Fujisaki S, Tanjoh K: The effects of neurotensin in the colon of patients with slow transit constipation. Hepatogastroenterology 2007;54:1662-1666. 